International Journal of Linguistics, Literature and Translation

ISSN: 2617-0299 (Online); ISSN: 2708-0099 (Print)

DOI: 10.32996/ijltt

Journal Homepage: www.al-kindipublisher.com/index.php/ijltt

\title{
Promoting Gender Equality Values in a Fiction Written by A Lombok Female Writer
}

\author{
Puspita Dewi ${ }^{1}$ 8(D) $\varangle$, Riyana Rizki Yuliatin ${ }^{2}$ 8(D), Sulmi Magfirah ${ }^{3}$ 8(D), Dian Eka sari ${ }^{4}$ (D) and Farida \\ Maricar 58 id \\ ${ }^{1}$ English Literature Study Program, Universitas Bumigora, West Nusa Tenggara, Indonesia \\ ${ }^{2}$ Department of Drama, Dance, and Music Education, Universitas Hamzanwadi, West Nusa Tenggara, Indonesia \\ ${ }^{3}$ English Literature Study Program, STBA Prayoga, West Sumatra, Indonesia \\ ${ }^{45}$ English Study Program, Universitas Khairun, North Maluku, Indonesia
}

Corresponding Author: Puspita Dewi, E-mail: puspitadewi@universitasbumigora.ac.id

ARTICLE INFORMATION ABSTRACT

Received: February 08, 2021

Accepted: March 10, 2021

Volume: 4

Issue: 3

DOI: 10.32996/ijllt.2021.4.3.2

\section{KEYWORDS}

Promoting, gender equality, values, short stories
Plenty of media is used, such as newspapers, magazines, novels, and movies to share information and incorporate some life values, including gender equality values. The collection of short stories entitled NING was written by Irma Argiyanti. She is an active Lombok writer. This research aims to identify the writer's ideology through the artwork (the short story collection). This methodological framework was adopted from Fairclough's concept of the three-dimensional model, explored gender representation in the short stories, and tried to identify the truth behind the texts' ideology. The results show that the stories represent implicitly and explicitly gender equality values. Therefore, the topics and the stories' flow provide patriarchy, women empowerment, and equality values in the family. Based on the data, there are about 33 words representing women's names and 19 words of men. Consequently, the short stories pursue the readers to think, elaborate, and accept gender equality values, and it is expected to implement in daily life and change to be a better society.

\section{Introduction}

Various values can be embedded and incorporated through media such as newspapers, magazines, novels, short stories, and other media because media is one way to influence and change people's perspectives and behaviours (Dewi and Magfirah, 2018). Media is one of the tools used for communication, for example, to persuade people to buy some products and influence people to agree with people's opinions and many other purposes. Magazines, newspaper, poems, novels, and short stories are tools to share information with the readers. Therefore, writers frequently incorporate ideology or values in writing.

Irma is a woman who is active in writing poems, short stories and novels in which her writing published in many newspaper and media such as Kompas, Horison, Media Indonesia, Tempo, Sinar Harapan, Bali Post, Lombok Post, and other media. She also joined many literature symposiums; one is the Makassar International Writers Festival. Through arts, poems, and short stories, Irma share and communicate with readers.

Communication is established from face to face and through written texts, including novel, newspapers, short stories, and many other text sources. Written texts are different from the spoken condition because they can directly see the speakers' expression and tune when delivering their thoughts and ideas. However, in written texts, both speakers and readers cannot identify the expression, so that sometimes texts can create misunderstanding. It is because texts have various meanings.

The readers interpret texts based on the knowledge and experiences gained. The collective stock of knowledge such as institution, organization, archives, socio-cognitive devices, texts, and all kinds of immaterialities become one unity (Wetzstein \& Huber, 2016). Experiences from different people (readers) have a pivotal role in constructing meanings of the texts and different occupations influence the way readers interpret the texts. For example, in this pandemic, texts of one issue (Covid-19) could be

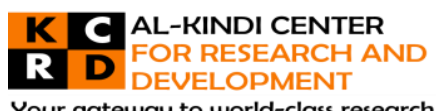

Your gateway to world-class research

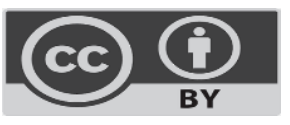

Published by Al-Kindi Center for Research and Development. Copyright (c) the author(s). This open access article is distributed under a Creative Commons Attribution (CC-BY) 4.0 license 
interpreted by various interpretations. For illustration, doctors and entrepreneurs have different perspectives of Covid-19. Mbembe (2017) stated that "social world of culture, history, language and economical - a world symbolically and semiotically constituted by humans" (Shaikjee \& Stroud, 2017, p.375).

The language used in the media creates perception and even shape social behaviours and attitudes. Language plays a pivotal role, and it is a symbol of communication, culture, and a sense of community (Stein-smith, 2019). Language consists of various words and becomes sentences. Through words and sentences, they are a tool to express ideas and feelings to communicate with each other.

Texts establish communication with the readers. Texts can be interpreted with various meaning, and via texts, people do interaction. All interaction, including reading, has various purposes: business, relaxation, information, and science or knowledge (Suraprajit, 2019). Texts also have expressions such as anger, happiness, sadness, humor, and other expression based on the tone of the texts or also called "productive mastery" that it is the process of communicating ideas, thoughts and feelings through forms of vocabulary (Asia et al., 2019, p.537). Texts establish meaning from texts, co-texts, and contexts.

\section{Literature Review}

Word selected or dictions used by the authors in communication represent various meanings; for example, when using codeswitching or code-mixing in written or oral contexts has implicit meaning. Narayan (2019) mentions that code-switching is used to express some expression such as anger, frustration, happiness, sadness, excitement and many other feelings. The way people talk and their expression also show different meanings depending on the situation, the topic and the people who speak; it depends on the discourse created between the speakers and listeners.

Discourse appeared in the texts and "pragmatic texts" (Song \& Xu, 2019, p.511) used for searching the specific context based on the vocabulary used and create meaning of the texts from the relationship among the sentences. In written texts, all components such as the vocabulary, grammar, syntax, and other linguistics components relate to one another. Texts are a sign, and the sign has various meaning depending on the previous and the after of the text, or even beyond the text. Schmittau (2005) and Wells (2007) noted about semiotic meditation that concepts of Vygotskian theory in which the tool used as a sign for something beyond itself (Chang et al., 2020). For instance, in some textbooks, students provide gender inequality concepts in the text by showing men who are always a leader and women as a follower. Implicitly, it creates gender bias in the texts.

Traditionally, women were constructed to obey men and women as subservient (Namatende-Sakwa, 2019). This situation and construction create patriarchy so that many human right activists and writers, through arts performance and written (novel and short stories) fight for gender equality and equity. There are many novels or short stories that tell about gender equality. Thereby, this article discusses short stories from Irma entitled "Ning" which consisted of 10 short stories written by Irma, one of the women writers from West Nusa Tenggara. Irma was a selected writer of Makassar International Writer Festival and had plenty of achievements.

Gender inequality is created from oral and written, such as in textbooks, short stories, and other written sources. Gender stereotypes are established because some people create a rule to become a habit. Callahan and Nicholas (2018, p.8) mention that the social power of gender labelling can be shown through the conversation between two children, Harry and Simon.

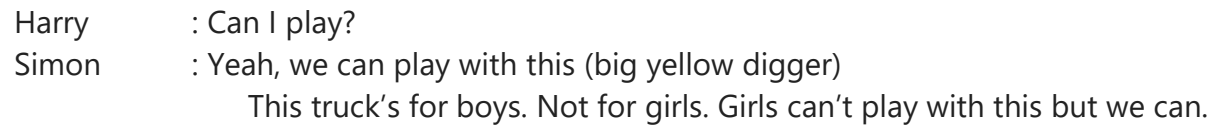

Gender bias or stereotype is created by society and environment either through verbal or non-verbal communication, including texts.

\section{Methodology}

This study tries to investigate the short story collection of 'Ning" written by Irma Agryanti. This study used a critical discourse analysis approach by combining with gender studies to provide more accurate results. Data was taken from all short stories to be analyzed. The short stories consist of ten series. All series were chosen as the corpus of the study. This methodological framework was adopted from Fairclough that is cited from Amerian and Esmaili (2015) taking Fairlough's concept of the threedimensional model was opted and adopted in conducting the research to elaborate and explore gender representation in short stories and tried to identify the truth of the ideology behind the texts through which gender is described. It is added with Fairclough (p.2 and p.62) concept that emphasized three types of constraints, namely constraints on contents, relations and subjects and points out and 'achieving coordination and commonality of practice in respect of knowledge and beliefs, social relationships, and social identities (Amerian \& Esmaili, 2015, p.6). This data also was analyzed based on the interview results from the writer (Ning) in the book review event. 


\section{Results and Discussion}

NING represents a strong woman and a symbol of strength. Women in a patriarchal society are usually regarded as beings without power, weak, under, inferior, serving, obedient and other characteristics. However, in the short story collection, Irma Argiyanti tries to discuss gender equality and promote gender justice. Irma deconstructs the existing order: helpless women become strong women, and women have principles. Based on the short stories, Irma has an effort to shape women from the other side. Almost all of the short stories explain women issues. Quantitatively, the number of women's names appears more than men. Based on the data, there are about 33 words representing women in these short stories and about 19 words of men.

Ning represents gender justice in which both men and women have the same rights in access to education, employment, and other sectors. Gender justice does not mean that women and men are the same biologically but gender equality speaks that women have the same opportunities as men in developing, innovating, leading, and others. Lyttleton-Smith mentions that "gender is characterized by doing, not being" (Lyttleton-Smith, 2019) and "functioning which are the beings and doings" (Shah \& Khurshid, 2019). Gender also is defined as "the differential experiences of men and women" (Yang et al., 2018). Gender is not pointed out of a biological aspect but social roles. Sharing roles in the family is crucial; women are represented by the words kitchen, wells, and mattresses and then men are identified with people who always go to work. The short story entitled "Lebah Lebah Lind (Lind Bees)" in chapter eight opens the concept of men and women's role in which men are not merely those who have to go to work and women who clean a house.

"Lind berangkat kerja, Tom akan mulai menyibukkan diri. Dia mulai membersihkan gitarnya, melatih dirinya dengan beberapa petikan, mendengarkan satu dua lagu,sesekali juga ia akan merapikan seisi rumah".

(Lind goes to work. Tom will begin to get busy. He starts to clean his guitar and practice, listen one till two music, sometimes he is also clean the house)

Irma provides a new paradigm in the story of gender in which women and men need to be more aware of gender equality. It is expected that the values of gender equality could be applied and implemented in daily life.

NING - a name, sometimes becomes a symbol of sexism formed by society. In the cultural aspect, either men or women could be identified from their names. For example, Ning, Siti, Ani and Hamidah are part of the names of women and vice versa Ahmad, Jaka, Budi, and other names represent men. In this case, "name" is not the core objective of this study, but it could be a polemic issue when someone is discredited merely because of their name and their sexes. No one of babies chooses the sexes when born so that no one could judge them because of their sexes; "individuals are born 'sexed' not 'gendered'" (Lee, 2014).

Related to one of the short stories entitled 'Laki-Laki Lain (other men)' in chapter five, the character of "I" (a male figure) mentioned, "parents like to give their daughter's name that is difficult to be pronounced" (p.43). Implicitly, this statement agrees with most males' perception that a woman is complicated, such as how they make decisions and the way they think. It is one of the social stereotypes because people stated unequal perception about women and unequal treatment to women.

Sexual violence is also one of the issues raised by Irma. At the end of the short story, Irma described a wife forced to have sex with her husband. Sexual violence is a result of gender injustice. Women are considered weak persons in a patriarchal culture to be a factor in sexual harassment to sexual violence (Dewi, 2019). Irma mentions this sexual violence in her short story "The Head Tree", where the husband forces his wife to have sex.

"masak mas masih ingin lagi." (Do you want more)

"Lho, aku kan bukan hantu?" ( Lho, I am not a gosh)

"jadi aku dimanfaatkan?" (Are you taking a benefit on me?)

"kalau begitu buat apa kamu aku kawini." (So, what for I get married with you)

Many people assume that women have one who is obligated to serve their husbands without considering their wives' condition. This misunderstanding is one of the causes of conflict (Durrani \& Halai, 2018).

In addition, Irma also considered one of the taboo issues, namely LGBT. In the short story entitled "another man", the writer describes "I (a man)" and "he" who have the same sex, love each other and establish a romantic love story relationship. Interestingly, in Irma's story, most of the heterosexual romantic stories end with sadness in which their affairs end happily.

In the short story "Voice from the Border", the male leader in the army tells the woman he likes by saying "... once brought me a hair ribbon". He said women should always look beautiful. A person can shape people into the figure he wants in various ways, one of which is negotiation. According to him, the male figure in the Voice of the Border negotiates with the woman he likes to 
become the ideal woman by giving goods or advice to the woman. Roth \& Stuedahl (2019, p.3) stating people will form themselves or others by interaction and negotiation.

This is in line with the short story "head tree" in which a father wants to shape his child as he wants by replacing his head. A father does not like his daughter, who is too smart and has principles, but he wants to shape his child into a not too smart but obedient woman. Although in his other short stories "Perempuan dan Penyair-Penyair (Women and Poets)" Irma shows that there are men who also want to intelligent women "But I can be sure that men actually need maturity of women with high intellectuals" (p.26).

Gender equality can also be defeated by love. Huang notes that the results of an analysis of a fairy-tale that women sometimes empower themselves by getting higher education but enslaved through love by men (Huang, 2018). It shows that women's power collapse because of love. At the end of the story, Irma story was a woman who never cried sobbed because her husband did not go back home. The short story entitled "Suara dari Perbatasan (Voice from the Border)" also mentions a woman cries because she remembered a man that she loves that is dead (p.22). However, Irma wants to show that women are deceived by love and men. It is not only women who can be enslaved by love as written in the article (Huang, 2018). Irma also shows that men can also be enslaved because of love in the short story of Satu Perihal Kita dalam Sebuah Kamar yang Kutulis pada Sebuah Kamar yang Lain (one issue in a room that I wrote in another room) "You who have the ability and power are more than enough ... it is now helpless by the love that you, yourself, are not understand "(p.59).

The last part of the short story "Pohon Kepala (Head Tree), reveals that the struggle ends in the absence of meaning where a woman (a child) who fights desperately upholds idealism and the principle but it ends with beheading and being thrown into a coconut's tree. The symbol of "Head" represents the intellectual of women in which a child and a wife died because of an authoritarian of a husband/father. The father killed his wife and child because of disobedience. Patriarchy is formed from oligarchy and authoritarianism, where men do not want to be confronted and want to be served. Therefore, the father does not want a too intelligent woman because the smarter the women, the harder it to be organized. When there are too smart women, they can be removed from power such as the workplace, family, and society. Arur and DeJaeghere (2019) state that if she had a good and smart education, some gender oppressions would change, including changes in society and family structure and fight for patriarchy.

At the end of the short story, Irma emphasizes that women have principles and full of power. The mother's and child's head, which ended up being beheaded, means that women's strength and consistence to hold their principles. They would rather die than follow the father's desire to replace the head (as a symbol of idealism and principles). It shows that power relations and power relations significantly affect patriarchy's existence. Power relations between children and parents have a pivotal role in how a child perceives and sees the world.

It is relevant to the story of Taliban, a woman from Pakistan, where religion, culture, family shape what she looks like and what the world looks at (Shah \& Khurshid, 2019). Adriany (2019) also mentioned that discourse could strengthen children or even vice versa can weaken them. Literary works can bring up a discourse that can strengthen children and women or even weaken them. Literary works become an essential part of changing the concepts of thinking and human consciousness because imagination has a place for human consciousness (Huang, 2018). The short stories "Ning" implicitly promote one of the SDGs targets that it is Gender Equality.

The interview results from Irma supported the literature analysis results. Even though Irma states that there are any intentions of embedding gender equality values in her writing; however, she wrote the short stories based on the social phenomena, for instance, sexual violence, child abuse, divorce, patriarchy and other phenomena. It means that Irma composed the story without realizing that she wrote a phenomenon of gender equality and equity in the short stories. Gender equality and equity issues still exist in Lombok in which Irma lived. Through stories, Irma tried to play the diction (texts) and create discourse to construct, inform, and promote gender equality values to build society's awareness. Consequently, the stories interfere with the readers' perception and attitudes. The sign, symbols, and dictions used in the short stories have meaning. Semiotic mediations provide meaningful contexts to influence the readers' perspectives and behaviors (Chang et al., 2020).

\section{Conclusion}

Verbal and non-verbal communications have meanings to express their feeling, idea, and opinion through novels, short stories, videos, and other tools. This article analyses short stories written By Irma Argiyanti entitled "NING". All short stories were read as samples. This methodological framework was adopted from the Fairclough concept of three-dimensional model to elaborate and explore gender representation in short stories and tried to identify the truth of the ideology behind the texts through which gender is described. The research results show that Irma tried to promote one of SDGs targets, namely the gender equality issue. 
Word choices and flow of the stories selected by Irma represent the gender equality concept embedded in the texts, and she tries to change the concept of patriarchy. Almost all the stories tell the social problems and relate to gender matters.

\section{References}

[1] Adriany, V. (2019). Being a princess: young children's negotiation of femininities in a Kindergarten classroom in Indonesia. Gender and Education, 31(6), 724-741. https://doi.org/10.1080/09540253.2018.1496229

[2] Amerian, M., \& Esmaili, F. (2015). Language and gender: A critical discourse analysis on gender representation in a series of international ELT textbooks. International Journal of Research Studies in Education, 4(2), 3-12. https://doi.org/10.5861/ijrse.2014.963

[3] Arur, A., \& DeJaeghere, J. (2019). Decolonizing life skills education for girls in Brahmanical India: a Dalitbahujan perspective. Gender and Education, 31(4), 490-507. https://doi.org/10.1080/09540253.2019.1594707

[4] Asia, A., Tolla, A., \& Salam, S. (2019). Indonesian Vocabulary Mastery of Early-aged Children in Paud Melati Makassar. Journal of Language Teaching and Research, 10(3), 535-540. https://doi.org/10.17507/jltr.1003.17

[5] Callahan, S., \& Nicholas, L. (2018). Dragon wings and butterfly wings: implicit gender binarism in early childhood early childhood. Gender and Education, O(0), 1-19. https://doi.org/10.1080/09540253.2018.1552361

[6] Chang, S., Torres-Guzmán, M. E., \& Waring, H. Z. (2020). Experiencing critical language awareness as a collective struggle: methodological innovations in language awareness workshops. Language Learning Journal, 48(3), 356-369. https://doi.org/10.1080/09571736.2020.1740769

[7] Dewi, P. (2019). Ketidakadilan Gender Dalam Novel Ronggeng Dukuh Paruk Karya Ahmad Tohari. Humanitatis: Journal on Language and Literature, 5(2), 100-115. https://doi.org/https://doi.org/10.30812/humanitatis.v5i2.456

[8] Dewi, P., \& Magfirah, S. (2018). Analisis wacana iklan rokok sampoerna mild. Humanitatis: Journal on Language and Literature, 5(1), 1-8. https://doi.org/https://doi.org/10.30812/humanitatis.v5i1.445

[9] Durrani, N., \& Halai, A. (2018). International Journal of Educational Development Dynamics of gender justice, con fl ict and social cohesion: Analysing educational reforms in Pakistan. International Journal of Educational Development, 61(November 2017), $27-39$. https://doi.org/10.1016/j.ijedudev.2017.11.010

[10] Huang, S. (2018). Postfeminist influences on fairy tales, real and imagined: a critical media literacy classroom investigation. Gender and Education, O(0), 1-17. https://doi.org/10.1080/09540253.2018.1467002

[11] Lee, J. F. K. (2014). A hidden curriculum in Japanese EFL textbooks: Gender representation. Linguistics and Education, $27,39-53$. https://doi.org/10.1016/j.linged.2014.07.002

[12] Lyttleton-Smith, J. (2019). Objects of conflict: (re) configuring early childhood experiences of gender in the preschool classroom. Gender and Education, 31(6), 655-672. https://doi.org/10.1080/09540253.2017.1332343

[13] Namatende-Sakwa, L. (2019). Networked texts: discourse, power and gender neutrality in Ugandan physics textbooks. Gender and Education, 31(3), 362-376. https://doi.org/10.1080/09540253.2018.1543858

[14] Narayan, R. (2019). Code-switching as a Linguistic Resource in the Fijian ESL Classrooms: Bane or Boon? Journal of Language Teaching and Research, 10(3), 427-436. https://doi.org/10.17507/jltr.1003.04

[15] Roth, S., \& Stuedahl, D. (2019). 'You Norwegians think we female Muslims are not free': enactment of gendered positional identities during transition stages. Gender and Education, 31(6), 756-773. https://doi.org/10.1080/09540253.2017.1387235

[16] Shah, P., \& Khurshid, A. (2019). Muslim womanhood, education, and empowerment: ethnographic reflections from Pakistan and India. Gender and Education, 31(4), 458-474. https://doi.org/10.1080/09540253.2018.1543859

[17] Shaikjee, M., \& Stroud, C. (2017). Fanon in drag: Decoloniality in sociolinguistics? Journal of Sociolinguistics, 21(3), 371-396. https://doi.org/10.1111/josl.12242

[18] Song, F., \& Xu, M. (2019). A New Paradigm for the Etymology and Trend Study from the Perspective of Culturomics. Journal of Language Teaching and Research, 10(3), 509-515. https://doi.org/10.17507/jltr.1003.14

[19] Stein-smith, K. (2019). Rethinking the Role of Languages in the US: Toward a More Diverse Cultural Identity. Journal of Language Teaching and Research, 10(3), 403-411. https://doi.org/http://dx.doi.org/10.17507/jltr.1003.01

[20] Suraprajit, P. (2019). Bottom-up vs Top-down Model: The Perception of Reading Strategies among Thai University Students. Journal of Language Teaching and Research, 10(3), 454-460. https://doi.org/10.17507/jltr.1003.07

[21] Wetzstein, I., \& Huber, B. (2016). Debating "alternative" gender identities: The online discourse triggered by 2014 life ball advertising posters. International Journal of Communication, 10(1), 432-450.

[22] Yang, Y. C. E., Passarelli, S., Lovell, R. J., \& Ringler, C. (2018). Gendered perspectives of ecosystem services: A systematic review. Ecosystem Services, 31, 58-67. https://doi.org/10.1016/j.ecoser.2018.03.015 